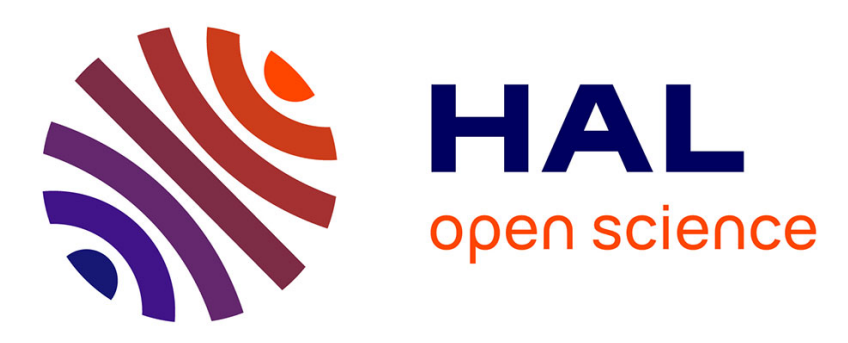

\title{
Iron-Catalyzed Dehydrogenative Borylation of Terminal Alkynes
}

Duo Wei, Bertrand Carboni, Jean-Baptiste Sortais, Christophe Darcel

\section{To cite this version:}

Duo Wei, Bertrand Carboni, Jean-Baptiste Sortais, Christophe Darcel. Iron-Catalyzed Dehydrogenative Borylation of Terminal Alkynes. Advanced Synthesis and Catalysis, 2018, 360 (19), pp.3649-3654. 10.1002/adsc.201800588 . hal-01902040

\section{HAL Id: hal-01902040 \\ https://hal-univ-rennes1.archives-ouvertes.fr/hal-01902040}

Submitted on 7 Nov 2018

HAL is a multi-disciplinary open access archive for the deposit and dissemination of scientific research documents, whether they are published or not. The documents may come from teaching and research institutions in France or abroad, or from public or private research centers.
L'archive ouverte pluridisciplinaire HAL, est destinée au dépôt et à la diffusion de documents scientifiques de niveau recherche, publiés ou non, émanant des établissements d'enseignement et de recherche français ou étrangers, des laboratoires publics ou privés. 


\title{
Iron-Catalyzed Dehydrogenative Borylation of Terminal Alkynes
}

\author{
Duo Wei, ${ }^{a}$ Bertrand Carboni, ${ }^{\text {a }}$ Jean-Baptiste Sortais, ${ }^{\text {a,b,c }}$ Christophe Darcel ${ }^{\mathrm{a} *}$ \\ a Univ Rennes, CNRS, ISCR (Institut des Sciences Chimiques de Rennes), UMR 6226, F-35042 Rennes, France \\ [33 223236271 ; christophe.darcel@univ-rennes1.fr] \\ b LCC-CNRS, Université de Toulouse, CNRS, UPS, Toulouse, France. \\ c Institut Universitaire de France, 1 rue Descartes, 75231 Paris Cedex 05, France.
}

\begin{abstract}
The catalytic system based on $\mathrm{Fe}(\mathrm{OTf})_{2}$ $(2.5 \mathrm{~mol} \%)$ and DABCO $(1 \mathrm{~mol} \%)$ selectively promotes the dehydrogenative borylation of both aromatic and aliphatic terminal alkynes to afford alkynylboronate derivatives in the presence of 1 equiv. of pinacolborane at $100{ }^{\circ} \mathrm{C}$ in toluene. This methodology is applicable to a variety of terminal alkynes (16 examples, yield: 62-93\%).
\end{abstract}

Keywords: Iron; alkyne; dehydrogenative borylation; pinacolborane; alkynylboronates

Thanks to the impressive progress made in SuzukiMiyaura coupling reactions, ${ }^{[1]}$ the selective preparation of organoboron compounds has attracted broad interest over the last two decades. ${ }^{[2]}$ More particularly, efficient accesses to these versatile intermediates by $\mathrm{C}-\mathrm{H}$ dehydrogenative borylation have been described.$^{[3]}$ In the area of metal-catalyzed hydroboration of alkenes and alkynes, a competing side reaction, namely the dehydrogenative borylation, can operate. However, an accurate design of the catalytic system can be performed to favor such pathway, then yielding alkenyl- or alkynyl-boronates from terminal alkenes or alkynes, respectively. ${ }^{[4]}$ Alkynylboronates are useful building blocks and are classically prepared by deprotonation of the corresponding alkynes by $n-\mathrm{BuLi}$, then reaction with a boric ester and finally quench with anhydrous acid. ${ }^{[5]}$ Transition metal catalyzed dehydrogenative borylation of terminal alkynes was only scarcely reported: the known catalytic systems are SiNN and PNP pincer iridium complexes, ${ }^{[6]}$ silver $^{[7]}$ or NHCcopper ${ }^{[8]}$ well defined complexes.

On the other hand, even if its catalytic ability has been demonstrated for a long time in the Haber process for ammonia production, ${ }^{[9]}$ iron catalysis has made a real breakthrough during the two last decades and is now able to compete favorably with noble metals. ${ }^{[10]}$
More particularly, there has recently been intense interest in developing first row transition metal complexes for catalytic hydroboration of alkenes, ${ }^{[1]}$ alkynes, ${ }^{[12]}$ and enynes. ${ }^{[13]}$ By contrast, the dehydrogenative hydroboration of alkenes was more scarcely reported. ${ }^{[14]}$

Here we describe the use of iron salt as catalyst for the selective dehydrogenative borylation of terminal alkynes leading to the corresponding alkynylboronates.

Our initial studies showed that the dehydrogenative borylation of $p$-tolylacetylene $\mathbf{a} 2$ could be achieved i. toluene solution at $100{ }^{\circ} \mathrm{C}$ for $72 \mathrm{~h}$ with 1 equiv. of $\mathrm{HBpin}$ ( pin = pinacolate) in the presence of $10 \mathrm{~mol}$ \%, of $\mathrm{Fe}(\mathrm{OTf})_{2}{ }^{[15-16]}$ as precatalyst, and $10 \mathrm{~mol} \%$ of pyridine in $67 \%$ conversion. The borylated $p$ tolylacetylene b2 was obtained as the major product $(87 \%)$ along with trace amounts of the hydroborated derivative c2 (7\%) and of 4-methylstyrene (5\%) (Table 1 , entry 1 ). The chemoselectivity decreased significantly when 2,6-lutidine, 2,2'-bipyridine or $\mathrm{Et}_{3} \mathrm{~N}$ (10 mol\%) was used as the base (entries 2-4). Upon screening various bases, DABCO was found to lead to both high conversion (84\%) and selectivity towards the formation of the borylated $p$ tolylacetylene $\mathbf{b 2}(87 \%)$ besides trace amounts of the alkenyl derivative c2 (10\%) and of 4-methylstyrene (3\%) (Entry 5).

$\mathrm{Fe}(\mathrm{OTf})_{2}$ and DABCO loadings can be efficiently decreased to $2.5 \mathrm{~mol} \%$ as full conversion was obtained after $72 \mathrm{~h}$ at $100{ }^{\circ} \mathrm{C}, \mathbf{b 2}$ being produce selectively in $84 \%$ NMR yield (entry 6). Decreasing the reaction time to $48 \mathrm{~h}$ led to lower conversion (90\%, entry 7). However, with only $1 \mathrm{~mol} \%$ of $\mathrm{Fe}(\mathrm{OTf})_{2}$ and DABCO, even with $90 \%$ conversion, the selectivity dropped $(\mathbf{b 2} / \mathbf{c 2}=45: 47$, entry 9). Noticeably, the addition of hydrogen scavengers such as norbornadiene or cyclooctene has a deleterious effect on the chemoselectivity of the reaction (entries 10-11). 
Table 1. Optimization of the reaction parameters for $p$ tolylacetylene. ${ }^{[\mathrm{a}]}$

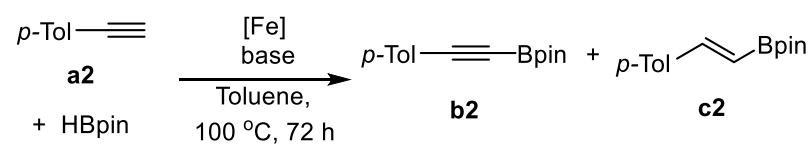

\begin{tabular}{|c|c|c|c|c|c|}
\hline Entry & $\begin{array}{c}{[\mathrm{Fe}]} \\
(\mathrm{mol} \%)\end{array}$ & $\begin{array}{c}\text { Base } \\
(\mathrm{mol} \%)\end{array}$ & $\begin{array}{c}\text { Conv. } \\
(\%)\end{array}$ & b2/c2 & $\begin{array}{c}\text { Yield } \\
(\%) \text { b2 }\end{array}$ \\
\hline 1 & $\begin{array}{c}\mathrm{Fe}(\mathrm{OTf})_{2} \\
\quad(10)\end{array}$ & $\begin{array}{l}\text { Pyridine } \\
(10)\end{array}$ & 76 & $87 / 7$ & 66 \\
\hline 2 & $\begin{array}{c}\mathrm{Fe}(\mathrm{OTf})_{2} \\
\quad(10)\end{array}$ & $\begin{array}{l}\text { 2,6-lutidine } \\
\text { (10) }\end{array}$ & 93 & $43 / 36$ & 40 \\
\hline 3 & $\begin{array}{c}\mathrm{Fe}(\mathrm{OTf})_{2} \\
\quad(10)\end{array}$ & $\begin{array}{l}\text { 2,2'-bipyr } \\
\text { (10) }\end{array}$ & 85 & $44 / 43$ & 37 \\
\hline 4 & $\begin{array}{l}\mathrm{Fe}(\mathrm{OTf})_{2} \\
\quad(10)\end{array}$ & $\begin{array}{r}\mathrm{Et}_{3} \mathrm{~N} \\
(10)\end{array}$ & 57 & $54 / 20$ & 31 \\
\hline 5 & $\begin{array}{l}\mathrm{Fe}(\mathrm{OTf})_{2} \\
\quad(10)\end{array}$ & $\begin{array}{c}\text { DABCO } \\
(10)\end{array}$ & 84 & $87 / 10$ & 73 \\
\hline 6 & $\begin{array}{l}\mathrm{Fe}(\mathrm{OTf})_{2} \\
\quad(2.5)\end{array}$ & $\begin{array}{c}\text { DABCO } \\
(2.5)\end{array}$ & 99 & $84 / 8$ & 83 \\
\hline 7 & $\begin{array}{l}\mathrm{Fe}(\mathrm{OTf})_{2} \\
\quad(2.5)\end{array}$ & $\begin{array}{c}\text { DABCO } \\
(2.5)\end{array}$ & 90 & $85 / 9$ & $77^{[\mathrm{b}]}$ \\
\hline 8 & $\begin{array}{c}\mathrm{Fe}(\mathrm{OTf})_{2} \\
\quad(2.5)\end{array}$ & $\begin{array}{c}\text { DABCO } \\
(1.0)\end{array}$ & 99 & $81 / 11$ & 80 \\
\hline 9 & $\begin{array}{l}\mathrm{Fe}(\mathrm{OTf})_{2} \\
\quad(1.0)\end{array}$ & $\begin{array}{c}\text { DABCO } \\
(1.0)\end{array}$ & 90 & $45 / 47$ & 41 \\
\hline 10 & $\begin{array}{l}\mathrm{Fe}(\mathrm{OTf})_{2} \\
\quad(2.5)\end{array}$ & $\begin{array}{c}\text { DABCO } \\
(1.0)\end{array}$ & 88 & $59 / 12$ & $52^{[\mathrm{c}]}$ \\
\hline 11 & $\begin{array}{c}\mathrm{Fe}(\mathrm{OTf})_{2} \\
\quad(2.5)\end{array}$ & $\begin{array}{c}\text { DABCO } \\
(1.0)\end{array}$ & 91 & $76 / 17$ & $69^{[\mathrm{d}]}$ \\
\hline 12 & None & $\begin{array}{c}\text { DABCO } \\
(5.0)\end{array}$ & $<1$ & - & $<1$ \\
\hline 13 & $\begin{array}{c}\mathrm{Fe}(\mathrm{OTf})_{2} \\
\quad(5.0)\end{array}$ & None & 80 & $34 / 29$ & 27 \\
\hline 14 & $\begin{array}{l}\mathrm{FeF}_{2} \\
(2.5)\end{array}$ & $\begin{array}{c}\text { DABCO } \\
(2.5)\end{array}$ & 99 & $24 / 58$ & 24 \\
\hline 15 & $\begin{array}{l}\mathrm{FeCl}_{2} \\
(2.5)\end{array}$ & $\begin{array}{c}\text { DABCO } \\
(2.5)\end{array}$ & 59 & $11 / 9$ & 6 \\
\hline 16 & $\begin{array}{c}\mathrm{FeBr}_{2} \\
(2.5)\end{array}$ & $\begin{array}{c}\text { DABCO } \\
(2.5)\end{array}$ & 99 & $42 / 24$ & 42 \\
\hline 17 & $\begin{array}{c}\mathrm{Fe}(\mathrm{OAc})_{2} \\
\quad(2.5)\end{array}$ & $\begin{array}{c}\text { DABCO } \\
(2.5)\end{array}$ & 98 & $33 / 44$ & 33 \\
\hline
\end{tabular}

[a] Reaction conditions: $\mathrm{Fe}(\mathrm{OTf})_{2}(2.5-10 \mathrm{~mol} \%)$, toluene $(0.5 \mathrm{~mL})$, alkyne $(0.5 \mathrm{mmol}), \mathrm{HBpin}(0.5 \mathrm{mmol})$ and base (1-10 mol\%) at $100{ }^{\circ} \mathrm{C}$ for $72 \mathrm{~h}$. Conversion and yield were measured by ${ }^{1} \mathrm{H}$ NMR analysis of the crude product, based on $\mathbf{a 2}$, and the identity of the products $\mathbf{b 2}$ and $\mathbf{c 2}$ was confirmed by GC-MS. [b] 48 h. ${ }^{[c]}$ with 2 equiv. of norbornadiene. ${ }^{[\mathrm{d}]}$ with 2 equiv. of cyclooctene. Bipyr: bipyridine; DABCO: 1,4-diazabicyclo[2.2.2]octane

Notably, using DABCO, without iron precursor, resulted in no activity (entry 12). By contrast, a low yield and selectivity was obtained using $\mathrm{Fe}(\mathrm{OTf})_{2}$ $(2.5 \mathrm{~mol} \%)$ without base, even if the conversion can reach $80 \%$, thus showing the crucial role of the DABCO catalytic additive on the efficiency and chemoselectivity of this transformation (entry 13 and SI).

The influence of the nature of the iron precursors was also investigated. $\mathrm{FeF}_{2}, \mathrm{FeBr}_{2}$ and $\mathrm{Fe}(\mathrm{OAc})_{2}$ $(2.5 \mathrm{~mol} \%)$ in association with DABCO $(2.5 \mathrm{~mol} \%)$ led to full conversion under standard conditions but with a lower selectivity towards b2 (24-42\%, entries 14-17), whereas $\mathrm{FeCl}_{2}$ was less active (entry 15). No improvement was observed when 2-methyl-THF, $\mathrm{Bu}_{2} \mathrm{O}$ and dimethylcarbonate were used as solvent (see Table S2). Hence, the optimal conditions selected to probe the substrate scope of the reaction are $2.5 \mathrm{~mol} \%$ of $\mathrm{Fe}(\mathrm{OTf})_{2}, 1.0 \mathrm{~mol} \%$ of DABCO, in toluene $(1 \mathrm{M})$ at $100{ }^{\circ} \mathrm{C}$ for $72 \mathrm{~h}$ (Table 2).

Phenylacetylene and arylacetylene derivatives bearing para-electron-donating substituents, e.g. $p$. methyl, $p$-tert-butyl or $p$-methoxy, led selectively to the corresponding borylated arylacetylene compounds b1-b4 with isolated yields up to $85 \%$ (Table 2, entries 1-4).

It is worth noting that electron-withdrawing substituted arylacetylene derivatives such as $p$ trifluoromethylphenylacetylene, required shorter reaction times $\left(24 \mathrm{~h}\right.$ instead of $72 \mathrm{~h}$ at $100{ }^{\circ} \mathrm{C}$, entry 5) to lead to the corresponding borylated acetylenic derivative b5 specifically obtained with $87 \%$ isolated yield. Interestingly, the extension of the reaction time to $72 \mathrm{~h}$ permitted to only obtain specifically pinacol (E)-styrylborane c5 in $92 \%$ yield (entry 6). This result suggests that the production of the hydroborylated compounds $\mathbf{c 5}$ could occur through the hydrogenation of the borylated acetyleni derivative b5. Noteworthy, the bis(ethynyl)benzene afforded selectively the bis(pinacolborylethynyl) benzene b6 in 93\% yield (entry 7).

In addition, the reaction can be also efficiently performed with 1-dodecyne or terminal akynes bearing a benzyloxy group, leading to the corresponding borylated alkynes b7-b9 in 78-93\% isolated yields (entries 8-10). Trimethylsilylacetylene is also a suitable starting material as the corresponding borylated compound b10 was isolated in $89 \%$ yield (entry 11 ).

Using alkadiynes such as 1,7-octadiyne or 1,6heptadiyne, the monofunctionalization was only observed in the presence of 2 equiv. of HBpin and the corresponding monoborylated derivatives b11 and b12 were obtained selectively in $70-72 \%$ isolated yields (entries 12 and 13). Noticeably, no trace of diborylated compounds was detected, the only byproducts observed in the crude mixture being the corresponding alkenyl borylated compounds resulting from the hydroborylation of one terminal triple bond.

With more steric demanding terminal alkynes such as tert-butylacetylene and cyclopropylacetylene, both dehydroborylation and borylated products were selectively obtained depending upon the reaction time. Pinacol tert-butylethynylborane b13 and pinacol cyclopropylethynylborane b14 were isolated in 62 and $63 \%$ yields, respectively, after $60 \mathrm{~h}$ and $36 \mathrm{~h}$ (entries 14 and 16). 
Table 2. Scope of the reaction. ${ }^{\text {[a] }}$

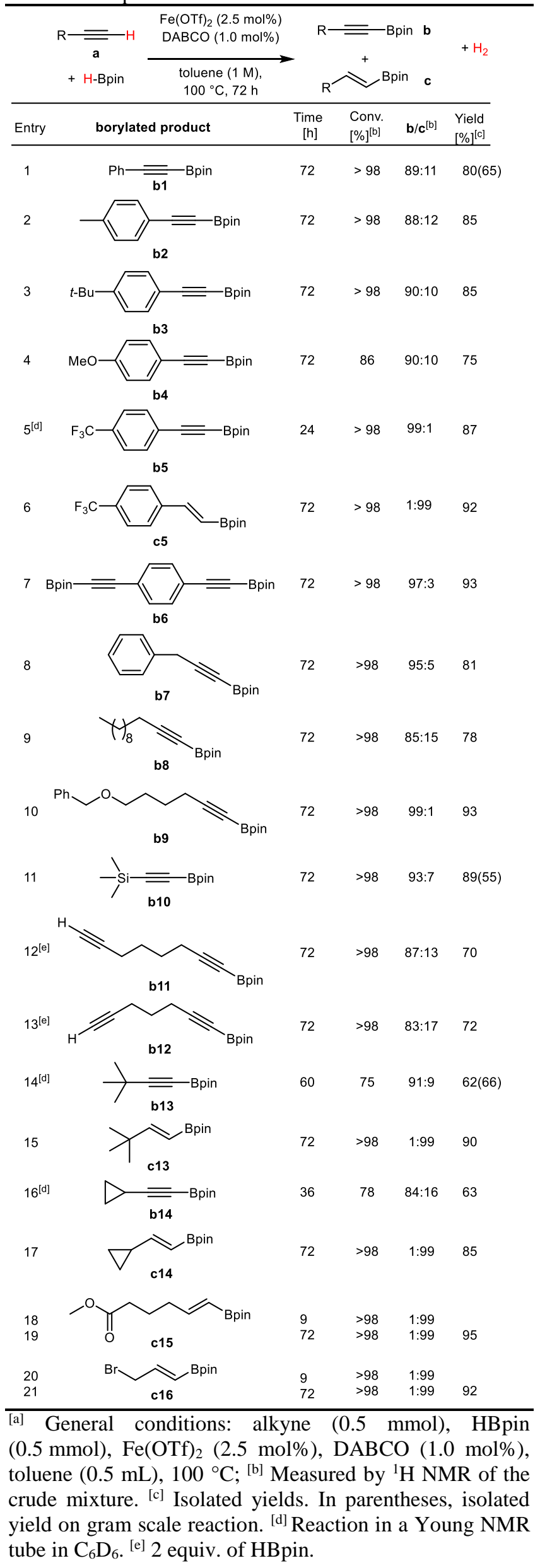

A prolonged $72 \mathrm{~h}$ of reaction permitted to switch the chemoselectivity as pinacol $(E)$-2-tert-butylvinylboranate c13 and pinacol (E)-2-cyclopropylvinylboranate c14 were selectively isolated in 85 and $90 \%$ yields, respectively (entries 15 and 17). Notably, cyclopropylacetylene furnished b14 and c14 in quantitative yield, which seem to indicate that the reaction did not proceed via stable radical intermediates.

Starting from methyl hex-6-ynoate or 3-bromo-1propyne, only the hydroborated derivative $\mathbf{c 1 5}$ and c16 were obtained in high yields, 95 and 92\%, respectively, whatever the reaction time, 9 or $72 \mathrm{~h}$ (entries 18 and 19). Additionally, under the optimized reaction conditions, no reaction was observed with terminal alkynes bearing primary amine, alcohol or carboxylic acid substituents (see Table S4).

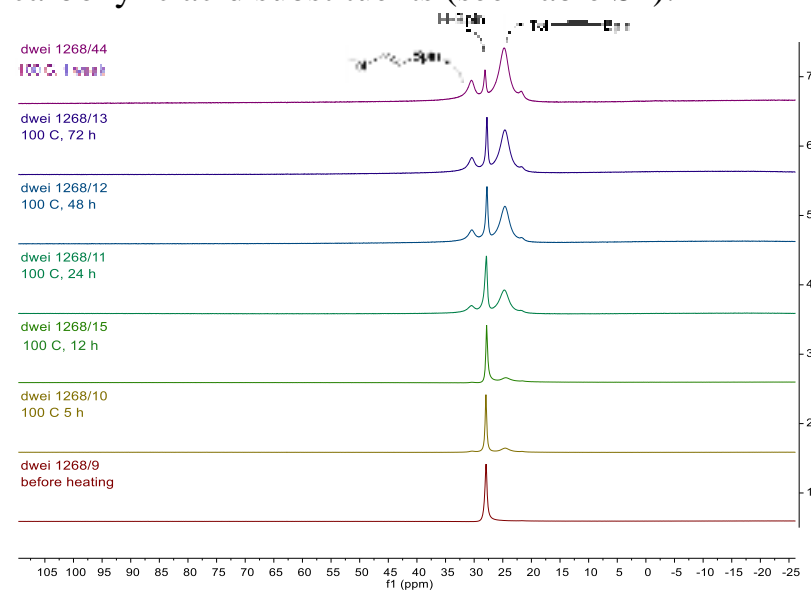

Figure 1: ${ }^{11} \mathrm{~B}$ NMR spectra recorded at $96 \mathrm{MHz}$ of th reaction of $p$-tolylacetylene $\mathbf{a} 2$ with $\mathrm{HBpin}$ in $\mathrm{C}_{6} \mathrm{D}_{6}$ at $100{ }^{\circ} \mathrm{C}$ leading to the compounds $\mathbf{b 2}$ and $\mathbf{c 2}$.

Preliminary experiments aimed at gaining an insight into the reaction course were then performed. The reaction outlined in Table 2, entry 2, was achieved in a Young NMR tube, charged under argon atmosphere with $2.5 \mathrm{~mol} \%$ of $\mathrm{Fe}(\mathrm{OTf})_{2}$ in $\mathrm{C}_{6} \mathrm{D}_{6}$ $(1.0 \mathrm{~mol} / \mathrm{L}), 0.5 \mathrm{mmol}$ of $\mathbf{a} 2,0.5 \mathrm{mmol}$ of $\mathrm{HBpin}$ and DABCO $(1 \mathrm{~mol} \%)$ at $100{ }^{\circ} \mathrm{C}$ for indicated time. Analysis of ${ }^{11} \mathrm{~B}$ NMR spectra showed that the dehydroborylated and the borylated compound b2 and $\mathbf{c 2}$ were formed simultaneously, $\mathbf{b 2}$ being always the major product (Figure 1). Additionally, the results described in Table 2, entries 6, 15 and 17 indicated that the formation of the alkenyl boronates result from the reduction of the corresponding alkynylboronates. On the other hand, the evolution of the $\mathrm{H}_{2}$ gas was also identified in ${ }^{1} \mathrm{H}$ NMR at 4.47 ppm (see Figure S2).

From a mechanistic point of view, as a Lewis acid, $\mathrm{Fe}(\mathrm{OTf})_{2}$ should be able to activate the $\mathrm{B}-\mathrm{H}$ bond, thus enhancing the electrophilic capacity of the boron center to react with acetylenic derivative. This process would be accelerated by the presence of DABCO which increases the nucleophilicity of the terminal acetylenic carbon. ${ }^{[17,18]}$ 
In summary, we have reported the first example of a highly selective catalytic dehydrogenative borylation of terminal alkynes with pinacolborane, using iron as an inexpensive earth abundant metal and $\mathrm{DABCO}$ as a co-catalyst. Further studies on the mechanism and synthetic applications are in progress in our laboratory.

\section{Experimental Section}

General procedure for $\mathrm{Fe}(\mathrm{OTf})_{2}$ catalyzed dehydrogenative borylation of terminal alkynes: in an argon filled glove box, a $20 \mathrm{~mL}$ Schlenk tube was charged with $\mathrm{Fe}(\mathrm{OTf})_{2} \quad(2.5 \mathrm{~mol} \%)$, toluene (1.0 $\mathrm{mol} / \mathrm{L})$, alkyne $(0.5 \mathrm{mmol})$, HBpin $(0.5 \mathrm{mmol})$ and DABCO (1 mol\%, stock solution in toluene) in this order. Then the reaction mixture was stirred at $100{ }^{\circ} \mathrm{C}$ for $72 \mathrm{~h}$. After cooling the mixture to room temperature, the solution was diluted with pentane (2 $\mathrm{mL})$ and filtered through a small pad of celite $(2 \mathrm{~cm}$ in a Pasteur pipette). The celite was washed with pentane $(2 \mathrm{~mL} \times 2)$. The filtrate was evaporated and the crude residue was then purified by recrystallization (slow evaporation form pentane) or bulb to bulb distillation.

\section{Acknowledgements}

We thank the Centre National de la Recherche Scientifique (CNRS), the Université de Rennes 1, the Institut Universitaire de France (IUF) and the Institut des Sciences Chimiques de Rennes (ISCR, Projet Inter-équipe B.C./J.-B.S)

\section{References}

[1] a) N. Miyaura, A. Suzuki, Chem. Rev. 1995, 95, 2457; b) N. Miyaura, Top. Curr. Chem. 2002, 219, 11. A. Suzuki, Angew. Chem., Int. Ed. 2011, 50, 6722; Angew. Chem 2011, 123, 6855; c) E. M. Beck, R. Hatley, M. J. Gaunt, Angew. Chem., Int. Ed. 2008, 47, 3004; Angew. Chem.2008, 120, 3046; d) A. D. Finke, J. S. Moore, Org. Lett. 2008, 10, 4851.

[2] a) Boronic Acids: Preparation, Applications in Organic Synthesis and Medicine, (Ed.: D. G. Hall), Wiley-VCH, Weinheim, 2011; b) Boron reagents in synthesis, Coca, A., Eds; ACS Symposium, Series 1236; American Chemical Society: Washington, DC, 2016; c) Synthesis and Application of Organoboron Compound, Fernández, E.; Whiting, A., Eds., Springer, New York, 2015.

[3] For examples of alkane C-H dehydroborylation, see: a) H. Chen, J. F. Hartwig, Angew. Chem., Int. Ed. 1999, 38, 3391; Angew. Chem. 1999, 111, 3597; b) H. Chen, S. Schlecht, T. C. Semple, J. F. Hartwig, Science 2000, 287, 1995; c) T. Ishiyama, K. Ishida, J. Takagi, N. Miyaura, Chem. Lett. 2001, 30, 1082; d) J. M. Murphy, J. D. Lawrence, K. Kawamura, C. Incarvito, J. F. Hartwig, J. Am. Chem. Soc. 2006, 128, 13684; e) V. J. Olsson, K. J. Szabó, Angew. Chem., Int. Ed. 2007, 46, 6891; Angew. Chem. 2007, 119, 7015; For examples of C-H arene dehydroborylation, see; f) J.-Y. Cho, M. K.
Tse, D. Holmes, R. E. Maleczka Jr, M. R. Smith III Science 2002, 295, 305; g) T. Ishiyama, J. Takagi, K. Ishida, N. Miyaura, N. R. Anastasi, J. F. Hartwig, J. Am. Chem. Soc. 2002, 124, 390; h) S. M. Preshlock, B. Ghaffari, P. E. Maligres, S. W. Krska, R. E. Maleczka Jr, M. R. Smith III, J. Am. Chem. Soc. 2013, 135, 7572 ; i) Q. Li, C. W. Liskey, J. F. Hartwig, J. Am. Chem. Soc. 2014, 136, 8755; j) S. H. Cho, J. F. Hartwig, Chem. Sci. 2014, 5, 694; k) B. Ghaffari, S. M. Preshlock, D. L. Plattner, R. J. Staples, P. E. Maligres, S. W. Krska, R. E. Maleczka Jr, M. R. Smith III, J. Am. Chem. Soc. 2014, 136, 14345; 1) T. Dombray, G. C. Werncke, S. Jiang, M. Grellier, L. Vendier, S. Bontemps, J.-B. Sortais, S. Sabo-Etienne, C. Darcel, J. Am. Chem. Soc. 2015, 137, 4062; For examples of alkene C-H dehydroborylation, see: m) J. M. Brown, G. C. Lloyd-Jones, J. Am. Chem. Soc. 1994, 116, 866; n) R. B. Coapes, F. E. S. Souza, R. L. Thomas, J. J. Hall, T. B. Marder, Chem. Commun. 2003, 614.

[4] For a representative review, see: S. J. Geier, S. A. Westcott, Rev. Inorg. Chem. 2015, 35, 69.

[5] H. C. Brown, N. G. Bhat, M. Srebnik, Tetrahedron Lett. 1988, 29, 2631.

[6] a) C.-I. Lee, J. Zhou, O. V. Ozerov, J. Am. Chem. Soc. 2013, 135, 3560; b) C.-I Lee, J. C. DeMott, C. J. Pell, A. Christopher, J. Zhou, N. Bhuvanesh, O. V. Ozerov, Chem. Sci. 2015, 6, 6572; c) J. Zhou, C.-I. Lee, O. V. Ozerov, ACS Catal. 2018, 8, 536.

[7] J.-R. Hu, L.-H. Liu, X. Hu, H.-D. Ye, Tetrahedron 2014, 70, 5815.

[8] E. A. Romero, R. Jazzar, G. Bertrand, Chem. Sci. 2017, $8,165$.

[9] For a review, see: R. Schlögl, Angew. Chem. Int. Ed. 2003, 42, 2004; Angew. Chem. 2003, 115, 2050.

[10] For representative selected reviews of the state of the art in iron catalysis, see: a) C. Bolm, J. Legros, J. Lo Paih, L. Zani, Chem. Rev. 2004, 104, 6217; b) Bernd Plietker in "Iron Catalysis in Organic Chemistry", Bernd Plietker Ed., WILEY-VCH Verlag, Weinheim, 2008; c) S. Enthaler, K. Junge, M. Beller, Angew. Chem. Int. Ed. 2008, 47, 3317; Angew. Chem.2008, 120, 3363; d) A. Correa, O. García Mancheño, C. Bolm, Chem. Soc. Rev. 2008, 37, 1108; e) B. D. Sherry, A. Fürstner, Acc. Chem. Res. 2008, 41, 1500; f) W. M. Czaplik, M. Mayer, J. Cvengroš, A. Jacobi von Wangelin, ChemSusChem. 2009, 2, 396; g) R. H. Morris, Chem. Soc. Rev. 2009, 38, 2282; h) C.-L. Sun, B.-J. Li, Z.-J. Shi, Chem. Rev. 2011, 111, 1293; i) K. Gopalaiah, Chem. Rev. 2013, 113, 3248; j) I. Bauer, H.J. Knölker, Chem. Rev. 2015, 115, 3170; k) A Fürstner, ACS Cent. Sci. 2016, 2, 778; 1) R. Shang, L. Ilies, E. Nakamura, Chem. Rev. 2017, 117, 9086; m) Special issue in Isr. J. Chem. 2017, 57, 1069-1221.

[11] With iron catalysts, see: a) J. Y. Wu, B. Moreau, T. Ritter, J. Am. Chem. Soc. 2009, 131, 12915; b) M. Haberberger, S. Enthaler, Chem. Asian J. 2013, 8, 50; c) J. V. Obligacion, P. J. Chirik, P. J. Org. Lett. 2013 15, 268; d) M. D. Greenhalgh, S. P. Thomas, Chem. Commun. 2013, 49, 11230; e) J. Zheng, J.-B. Sortais, C. Darcel, ChemCatChem 2014, 6, 763; f) V. S. Rawat, B. Sreedhar, Synlett 2014, 25, 1132; g) M. EspinalViguri, C. R. Woof, R. L. Webster, Chem. - Eur. J. 
2016, 22, 11605; h) A. J. MacNair, C. R. P. Millet, G. S. Nichol, A. Ironmonger, S. P. Thomas, ACS Catal. 2016, 6, 7217; i) C. Chen, X. Shen, J. Chen, X. Hong, Z. Lu, Org. Lett. 2017, 19, 5422; with cobalt catalysts, see: j) J. V. Obligacion, P. J. Chirik, J. Am. Chem. Soc. 2013, 51, 19107; k) L. Zhang, Z. Q. Zuo, X. B. Leng, Z. Huang, Z. Angew. Chem., Int. Ed. 2014, 53, 2696; Angew. Chem. 2014, 126, 2734; 1) A. J. Ruddy, O. L. Sydora, B. L. Small, M. Stradiotto, L. Turculet, Chem. Eur. J. 2014, 20, 13918; m) L. Zhang, Z. Zuo, X. Wan, Z. Huang, J. Am. Chem. Soc. 2014, 136, 15501; n) J. Chen, T. Xi, X. Ren, B. Cheng, J. Guo, L. Zhan, Org. Chem. Front. 2014, 20, 13918; o) W. N. Palmer, T. Diao, I. Pappas, P. J. Chirik, ACS Catal. 2015, 5, 622; p) M. L. Scheuermann, E. J. Johnson, P. J. Chirik, Org. Lett. 2015, 17, 2716; q) Y. Liu, Y. Zhou, H. Wang, J. Qu, RSC Adv., 2015, 5, 73705; r) X. Chen, Z. Cheng, Z. Lu, Org. Lett. 2017, 19, 969; with nickel, see: s) M. Zaidlewicz, J. Meller, Tetrahedron Lett. 1997, 38, 7279; t) R. J. Ely, J. P. Morken, J. Am. Chem. Soc. 2010, 132, 2534; u) Z. Yu, R. J. Ely, J. P. Morken, Angew. Chem., Int. Ed. 2014, 53, 9632; Angew. Chem., 2014, 126, 9786; v) E. E. Touney, R. Van Hoveln, C. T. Buttke, M. D. Freidberg, M. D., Organometallics 2016, 35, 3436; w) I. A. Guzei, J. M. Schomaker, Organometallics 2016, 35, 3436; with manganese, see: x) G.-Q. Zhang, H.-S. Zeng, J. Wu, Z.W. Yin, S.-P. Zheng, J. C. Fettinger, Angew. Chem., Int. Ed. 2016, 55, 14369; Angew. Chem.2016, 128, 1414581 .

[12] With iron catalysts, see: a) J. V. Obligacion, P. J. Chirik, Org. Lett. 2013, 15, 2680; b) M. D. Greenhalgh, S. P. Thomas, Chem. Commun. 2013, 49, 11230; with cobalt see: c) J. V. Obligacion, J. M. Neely, A. N.
Yazdani, I. Pappas, P. J. Chirik, J. Am. Chem. Soc. 2015, 137, 5855; with copper, see: d) E. A. Romero, R. Jazzar, G. Bertrand, J. Organomet. Chem. 2017, 829, 11.

[13] a) S. Jiang, S. Quintero-Duque, T. Roisnel, V. Dorcet, M. Grellier, E. Sabo-Etienne, C. Darcel, J.-B. Sortais, Dalton Trans. 2016, 45, 11101; b) C. Wang, C. Wu, S. Ge, ACS Catal. 2016, 6, 7585.

[14] a) N. Cabrera-Lobera, P. Rodríguez-Salamanca, J. C. Nieto-Carmona, E. Buñuel, D. J. Cárdenas, Chem. Eur. J. 2018, 24, 784; b) T. Xi, Z. Lu, ACS Catal. 2017, 7, 1181; c) S. Yu, C. Wu, S. Ge, J. Am. Chem. Soc. 2017, $139,6526$.

[15] Iron(II) trifluoromethanesulfonate, $98 \%$ purchased from Strem was used for this study. ICP -OES analysis was performed on this complex, see the Supporting Information Table $\mathrm{S} 1$. For a critical review about impurities in catalysis see: I. Thomé, A. Nijs, C. Bolm, Chem. Soc. Rev. 2012, 41, 979.

[16] Notably, under the optimized conditions, the use of $2.5 \mathrm{~mol} \%$ of $\mathrm{Ag}(\mathrm{OTf})_{2}, \mathrm{Ni}(\mathrm{OAc})_{2}, \mathrm{RuCl}_{3} \bullet \mathrm{xH}_{2} \mathrm{O}$ did not lead to the dehydrogenative compound. (see the Supporting Information Table S3).

[17] T. Tsuchimoto, H. Utsugi, T. Sugiura, S. Horio, $A d v$. Synth. Catal. 2015, 357, 77.

[18] In ${ }^{1} \mathrm{H}$ - and ${ }^{11} \mathrm{~B}-\mathrm{NMR}$ data collected during the mechanism study, it was sometimes possible to observe very small peaks around the baseline at -5.00 and +62.7 ppm, respectively, which may correspond to $\mathrm{Fe}-\mathrm{H}$ and $\mathrm{Fe}-\mathrm{B}$ species. Unfortunately, we were not able to isolate and fully characterize them in stoichiometric reaction. See references 31 and 11e. 


\section{COMMUNICATION}

Iron-catalyzed Dehydrogenative Borylation of Terminal Alkynes

Adv. Synth. Catal. Year, Volume, Page - Page

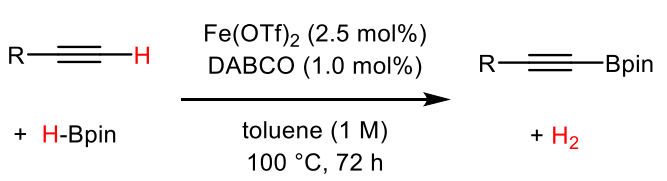

D. Wei, B. Carboni, J.-B. Sortais, C. Darcel* 